\title{
タイにおける栄養素摂取量の推定方法に関する研究 一青年期タイ人のためのFFQの開発および妥当性の検討一
}

Estimation of the nutrient intake in Thailand -Evaluation of semi-quantitative food frequency questionnaires to assess habitual dietary intake in young Thai-

小林 実夏 ${ }^{1}$, 高田 祐里 $^{2}$, 宇都宮 由佳 ${ }^{3}$, Saowapa Sakkayaphan ${ }^{4}$

1 大妻女子大学家政学部食物学科, ${ }^{2}$ 大妻女子大学短期大学部家政科, 3 青山学院女子短期大学現代教養学科, ${ }^{4}$ チェンマイ・ラジャバット大学科学技術学部

Minatsu Kobayashi ${ }^{1}$, Yuri Takada ${ }^{2}$, Yuka Utsunomiya ${ }^{3}$, and Saowapa Sakkayaphan ${ }^{4}$

${ }^{1}$ Department of Food Science, Faculty of Home Economics, Otsuma Women's University 12 Sanban-cho, Chiyoda-ku, Tokyo, Japan 102-8357

${ }^{2}$ Department of Domestic Science, Junior College Division, Otsuma Women's University 12 Sanban-cho, Chiyoda-ku, Tokyo, Japan 102-8357

${ }^{3}$ Department of Contemporary Liberal Arts, Aoyama Gakuin Women's Junior College 4-4-25 Shibuya, Shibuya-ku, Tokyo, Japan 150-8366

${ }^{4}$ Faculty of Science and technology, International College Chiang Mai Rajabhat University 202 Changpuak Road, Muang district, Chiang Mai, Thailand 50300

キーワード : 栄養素摂取量, 食物摂取頻度調查票, 青年期タイ人

Key words : Nutrient intake, Food frequency questionnaire, Young Thai

\section{抄録}

青年期タイ人から習慣的な栄養素摂取量を把握するため 2 種類の半定量式食物摂取頻度調査票を 開発した。 ひとつは, 日本人の栄養素攝取量評価に用いるSFFQを青年期タイ人 56 人に行った食事 記録調査をもとに改編した調査票（Thai_FFQ1），もうひとつはタイの国民栄養調査で使用してい る食物摂取頻度調査票に目安量を設定した調査票（Thai_FFQ2）である.Thai_FFQ2による解答の 精度を上げるために目安量ごとに掲載した写真集を開発した. Thai_FFQ1, Thai_FFQ2それぞれに ついて，荷重平均成分表も開発した。

252 人の青年期タイ人に実施したThai_FFQ1, Thai_FFQ2のデータから推定された栄養素摂取量は 高い相関を示したことから，青年期タイ人の習慣的な栄養素摂取量を把握するために利用できる 可能性が示唆された.

\section{1. 緒言}

食環境は，社会経済情勢の変化に伴う食料供給 の質と量の変化, 生産・流通・消費形態の変化によ り大きくしかも短期間で変化するため, 日本で問 題となっている食に起因する様々な健康問題は夕 イ（特にバンコク・チェンマイなどの都市）におい て同様に起きている ${ }^{[1,2]}$. わが国では食行動の多様 化が進む中で, 朝食欠食, 孤食, 偏った栄養摂取, 肥満傾向の増加, 過度の瘦身志向などがみられ, 生 活習慣病と食生活との関連も指摘されているが ${ }^{[3]}$,
これらの食に起因する健康問題を解決することは タイにおいても今後重要な課題となっていくこと は予想される.

しかしながら，タイでは食習慣や健康リスクを 評価する方法が確立されておらず，食品・栄養素 摂取量を把握して食文化, 食環境, 食習慣, 健康 リスクの相互関連性について検討した研究は実施 されていない.

本研究では, 青年期タイ人から習慣的な栄養素 摂取量を把握するため 2 種類の半定量式食物摂取 
頻度調査票を開発し，算出した食品・栄養素摂取 量の比較をすることによって，タイにおける栄養 素摂取量の推定方法に関する評価を行う。

\section{2. 方法}

2.1. 食物摂取頻度調查票の開発

(1)半定量食物摂取頻度調査票 (FFQ1)

平成 23 年 8 月に, チェンマイ・ラジャバット大 学の学生 $(\mathrm{n}=73)$ を対象に 2 日間の食事記録調査を 行った. 2 日日間の調査回答を得られた者 $(\mathrm{n}=56)$ の調査結果から, 摂取頻度の多い食品を抽出し た. 青年期日本人の栄養素摂取量推定に用いる半 定量食物摄取頻度調査票 ${ }^{[4]}$ の食品項目からタイ では摂取頻度が少ない食品を削除し，上記調査で 抽出された摂取頻度の多い食品を追加して, 80 食品項目の半定量食物摂取頻度調査票(FFQ1)を開 発した。調查は過去 1 年間の平均的な摂取頻度を 「食べなかった」「月に 1 回以下」「月に2-3 回」 「週に 1 回」「週に 2-3 回」「週に 4-6 回」「毎日 1 回」「毎日 2 回以上」の中から選択し，1 回に攝 取する量を目安量に比べて「5 割減」「2-3 割減」 「同じくらい」「2-3 割り増」「5 割増し以上」の 中から選択する.

(2)半定量食物摂取頻度調査票（FFQ2）

タイでは 2009 年に第 4 回国民健康調查（The Fourth National Health Examination Survey, NHES4）の中で栄養調査が実施されている ${ }^{[5]}$. 使用された食物摂取頻度調査票には目安量の記載 がなく，摂取量を算出できない。そこで，新たに アルコール・嗜好飲料を加え，目安量を設定して 113 食品項目の半定量食物摂取頻度調查票

（FFQ2）を開発した。調査は過去 1 年間の平均 的な摂取頻度を「食べなかった」「月に 1 回未 満」「月に 1-3 回」「週に 1-3 回」「週に 4-6 回」「1 日 1 回以上」の中から選択し, 1 回に摂取する量 を目安量に比べて「半分以下」「同じくらい」「2 倍以上」の中から選択する。目安量を正確に把握 してもらうために，各食品について目安量の写真 を撮影し, FFQ2 のための食品目安量写真集を開 発し，調査の際には写真集を見ながら 1 回に摂取 する量を回答してもらうこととした.

Table 1 に, FFQ1 および FFQ2 のみに掲載され ている食品項目を示す。
2.2. 調査の実施

(1)対象者

タイ王国チェンマイ・ラジャバット大学に在籍 する大学生 266 名（女性 220 名, 男性 46 名）を 対象とし，身体測定と食物摂取頻度調查

（FFQ1，FFQ2）を実施した。調査結果の集計 後, 各 FFQ への回答に 3 分の 2 以上の欠損があ った 14 名を除外し，252 名（女性 208 名，男性 44 名）を解析対象とした。対象者に対し本研究 の主旨，個人情報保護方針，調査の結果は集団と して解析されることについて十分な説明を行い， 調査への回答をもってその旨に同意したとみなし た。 なお，本研究の倫理的配慮については，大妻 女子大学の倫理審査委員会の承認を得ている

(2014 年 7 月 2 日付).

\section{(2)調查方法}

調查は, 2014 年 9 月 3-5 日と 2015 年 9 月 2-4 日のいずれか 1 日に実施された。身体測定とし て，体重，体脂肪率，基礎代謝量，推定骨量，筋 肉量を, 左右部位別体組成計インナースキャン BC-611（タニタ製）を用いて測定した。身体測 定後に，FFQ1，FFQ2，食品目安量写真集を配布 し, FFQ1，FFQ2への回答を同時に得た。

(3)栄養素摂取量の算出

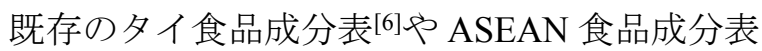
[7]には，掲載されている栄養素の種類が少ないた め, 日本食品成分表 $2010^{[8]}$ 使用して, FFQ1, FFQ2 に掲載されている食品項目について荷重食 品成分表を作成し，栄養素の算出を行った。

\section{3. 統計解析}

FFQ1，FFQ2 から計算されたエネルギーおよび 51 種類の栄養素について, 平均值, 標準偏差, 中央值，および摂取量の差を下記の式にて算出し た.

\%difference $=(\mathrm{FFQ} 2-\mathrm{FFQ} 1) / \mathrm{FFQ} 2 * 100$

FFQ1 から計算された栄養素と FFQ2 から計算 された栄養素のスピアマン順位相関を算出した. FFQ2 から計算された栄養素の摂取量によって対 象者を 3 分位にし, 各群の FFQ1 から計算された 栄養素摂取量の平均值を算出し, カテゴリーの完 全一致度 $(\%)$ を算出した。本解析には，SAS 
ver.9.4（SAS Institute Inc.）を用い，有意水準は $5 \%$ （両側検定）とした.

\section{3. 結果}

\section{1. 対象者の特徵}

調査時の平均年齢は女性 $20.2 \pm 1.5$ 歳, 男性 $20.7 \pm 1.5$ 歳であった。 BMI が 25 以上の肥満傾向 の人は女性 $25.0 \%$ ，男性 $31.8 \% ， 18.5$ 未満の瘦せ は女性 $23.1 \%$ ，男性 $13.6 \%$ であった。肥満傾向の 割合は, タイ国の NHES4 における 15-29 歳の女 性の割合(20.6\%), 同男性の割合(18.5\%)に比べて 高值であった[9] (table 2).

\section{2. 平均值の差，相関係数による評価}

エネルギーおよび 48 栄養素のうち，FFQ2 から 推定された栄養素が FFQ1 から推定された栄養素 より多かったのは女性では 35 種類, 男性では 22 種類, FFQ1 から推定された栄養素が FFQ2 から 推定された栄養素より多かったのは女性では 8 種 類，男性では 9 種類であった。FFQ1 から推定さ れた值のほうが高かった栄養素のうち, 食塩, $\beta$ カロテン, ビタミン $\mathrm{K}$ は男女で，ヨウ素， $\gamma$ トコ フェロールは男性で FFQ2 から推定された值の 2 倍以上であった。

FFQ1 と FFQ2 から推定されたエネルギーと 48 栄養素の相関係数は女性では 0.30-0.72 の範囲, 男性では 0.48-0.79 の範囲であり，男女ともエネ ルギーとすべての栄養素で有意な相関がみられた $(\mathrm{p}<0.001)$. もっとも相関係数の高かったのは，女 性ではリン $(\mathrm{r}=0.72)$, 男性ではマグネシウム (r=0.79)であった（table 3, 4).

\section{3. カテゴリーの一致率による評価}

FFQ2 から計算された栄養素の摂取量によって 対象者を 3 分位にし, 各群の FFQ1 から計算され た栄養素栄養素摂取量の平均值を算出した結果, 男女ともエネルギーおよびすべての栄養素で, FFQ2 から推定された摂取量が多い群ほど FFQ1 から推定された摂取量の平均值は高くなる傾向が みられた. 3 分位のカテゴリーの完全一致率の平 均值は女性では 54.4\%，男性では 58.6\%であっ た。もっとも一致率の高かったのは，男女ともパ ントテン酸(100\%)であり，2 番目に一致率の高か ったのは女性ではリン $(65.4 \%)$, 男性では $\alpha$ トコ フェロール(75.0\%)であった（table 5，6）。

\section{4. 考察}

青年期タイ人から習慣的な栄養素摂取量を把握 するために開発した FFQ1 と FFQ2 から算出され たエネルギーおよび栄養素摂取量の相関は高く, 3 分位のカテゴリーの完全一致率も高かった.

タイ国では，1991 年に第 1 回国民健康調査

（NHES1）が実施され，その後約 5 年に 1 回行わ れてきた NHES は 5 回目を迎えている.4 回目の NHES からは，24 時間思い出し法や食物摂取頻度 調査法を用いた栄養調査も行われている[9]. しか し，栄養調査法の開発，妥当性や再現性について 評価がされていない. NHES4 の結果も就学前の 子供の栄養摂取については報告があるが[10]，青年 期の栄養摂取については報告されていない.

本研究の FFQ1 と FFQ2 から推定されたエネル ギーと 48 栄養素の相関係数はすべて有意であっ たが，摂取量の平均值には差がある栄養素があつ た. 特に, 食塩, $\beta$ カロテン, ビタミン $\mathrm{K}$ は男女 とも FFQ1 から推定された值のほうが高かった。

食塩は，FFQ1 からの摂取量が，女性では 240\%，男性では 337\%高值であった。 $100 \mathrm{~g}$ 当た り食塩含有量が $5 \mathrm{~g}$ 以上の食品は, FFQ1 ではナン プラー $(16.0 \mathrm{~g} / 100 \mathrm{~g})$, ソース $(8.4 \mathrm{~g} / 100 \mathrm{~g})$ であり, FFQ2 では果物の塩漬け $(22.1 \mathrm{~g} / 100 \mathrm{~g})$, 塩漬け魚 $(14.3 \mathrm{~g} / 100 \mathrm{~g})$, 発酵食品塩漬け魚 $(14.3 \mathrm{~g} / 100 \mathrm{~g})$, ナ ムプリックプラーラー $(14.3 \mathrm{~g} / 100 \mathrm{~g})$, ゲーンペッド $(10.7 \mathrm{~g} / 100 \mathrm{~g})$ であった。 FFQ2 のほうが食塩含有量 の多い食品の掲載数が多いが，週に 1 回以上摂取 する食品は FFQ1 に載っているナンプラーは 63\%，ソースは 36\%であるのに対し，FFQ2 に載 っているゲーンペッド $22 \%$ ，果物の塩漬け $19 \%$ ，発酵食品塩漬け魚 $13 \%$ ，ナムプリックプラ ーラー $11 \%$ ，塩漬け魚は 1\%であった。タイでは 味付けの基本はナンプラーであり [11]，多くの料理 に使用されるため摂取頻度が高い. FFQ2 に掲載 されている食品はNHES4 の質問票に記載のある 食品項目であるが，タイの伝統食品であり，青年 期タイ人の摂取頻度は少なかった。一方，FFQ2 では調味料の項目がないため, 料理から摂取され た食塩しか計算されなかった。このため, FFQ1 の食塩摂取量が多くなったものと思われ，FFQ1 から計算された食塩摂取量が本研究対象者の習慣 的食塩摂取量を反映しているのではないかと考え られる。

$\beta$ カロテンは, FFQ1 からの摂取量が, 女性で は 390\%，男性では 434\%高值であった。 $100 \mathrm{~g}$ 当 
たり $\beta$ カロテン含有量が $100 \mu \mathrm{g}$ 以上の食品は, FFQ1 では緑の野菜 $(4,300 \mu \mathrm{g} / 100 \mathrm{~g})$, かぼちや $(3,500 \mu \mathrm{g} / 100 \mathrm{~g})$, のり $(2,700 \mu \mathrm{g} / 100 \mathrm{~g}), \quad$ トマト $(540$ $\mu \mathrm{g} / 100 \mathrm{~g})$, ケチャップ(670 $\mu \mathrm{g} / 100 \mathrm{~g})$, トマトジュ ース $(350 \mu \mathrm{g} / 100 \mathrm{~g})$ であり, FFQ2 ではナムプリッ クヌム $(7200 \mu \mathrm{g} / 100 \mathrm{~g})$, プルーン $(1,100 \mu \mathrm{g} / 100 \mathrm{~g})$, 野菜の塩漬け $(822 \mu \mathrm{g} / 100 \mathrm{~g})$, ゲーンオム $(824 \mu \mathrm{g}$ $/ 100 \mathrm{~g})$, マンゴー $(610 \mu \mathrm{g} / 100 \mathrm{~g}), \quad ク ゙ ァ ハ ゙(580 \mu \mathrm{g}$ $/ 100 \mathrm{~g})$, フトモモ $(580 \mu \mathrm{g} / 100 \mathrm{~g})$, 野菜ジュース $(350$ $\mu \mathrm{g} / 100 \mathrm{~g})$ ，ネーム(216 $\mu \mathrm{g} / 100 \mathrm{~g})$ であった。週に 1 回以上摂取する食品は FFQ1 に載っている緑色の 野菜は $86 \%$ ，黄色の野菜は $56 \%$ ，赤色の野菜は $56 \%$ ，ケチャップは 40\%であるのに対し， FFQ2 に載っているグァバは $31 \%$ ，ナムプリックヌムは 25\%，フトモモは $22 \%$ ，ゲーンオムは $18 \%$ ，野菜

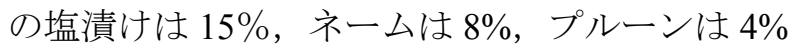
であった. FFQ1 に載っている緑の野菜の $\beta$ カロ テン含有量は高く，摂取頻度も高かった．FFQ2 には野菜類の食品項目は野菜の塩漬けのみであっ たことが，FFQ1の $\beta$ カロテン摂取量が多くなっ た理由である。青年期タイ人の緑の野菜，黄色の 野菜，赤色の野菜の摂取頻度が高かったことか

ら，FFQにこれらの食品項目を掲載するべきであ り, FFQ1 から計算された $\beta$ カロテン摂取量が本 研究対象者の習慣的 $\beta$ カロテン摂取量を反映して いるのではないかと考えられる.

ビタミン $\mathrm{K}$ は，FFQ1 からの摂取量が，女性で は $360 \%$ ，男性では $243 \%$ 高值であった。 $100 \mathrm{~g}$ 当 たりビタミン $\mathrm{K}$ 含有量が $50 \mathrm{~g}$ 以上の食品は, FFQ1 では糸引き納豆 $(870 \mu \mathrm{g} / 100 \mathrm{~g})$, のり $(520 \mu \mathrm{g}$ $/ 100 \mathrm{~g})$, 緑の野菜 $(250 \mu \mathrm{g} / 100 \mathrm{~g})$, わかめ・昆布(140 $\mu \mathrm{g} / 100 \mathrm{~g})$, 鶏肉脂身あり $(53 \mu \mathrm{g} / 100 \mathrm{~g})$ であり, FFQ2 では納豆 $(870 \mu \mathrm{g} / 100 \mathrm{~g})$, 鶏肉脂身あり $(153 \mu \mathrm{g}$ $/ 100 \mathrm{~g})$, 豆腐加工品 $(68 \mu \mathrm{g} / 100 \mathrm{~g})$, 揚げ物鷂肉(67 $\mu \mathrm{g} / 100 \mathrm{~g})$, 野菜の塩漬け $(60 \mu \mathrm{g} / 100 \mathrm{~g})$ であった。 週 に 1 回以上摂取する食品は FFQ1 に載っている緑 の野菜は $86 \%$, 鶏肉脂身ありは $45 \%$, のりは $28 \%$ ，わかめ・昆布は $18 \%$, 納豆は $6 \%$ であるの に対し，FFQ2 でも鶏肉脂身ありでは $18 \%$ ，揚げ 物鷂肉は $17 \%$, 野菜の塩漬けは $15 \%$ であった が，納豆 $4 \%$, 豆腐加工品 $2 \%$ であった. ビタミン $\mathrm{K}$ は，納豆に多く含まれているが，青年期タイ人 摂取頻度は少ない。ビタミン $\mathrm{K}$ 摂取量の差には FFQ1 にのみ掲載のある緑の野菜からの摂取量が 影響していると思われる.

本研究で開発した FFQ1の食品項目は，青年期
タイ人の 2 日間の食事記録調査から摂取頻度の高 い食品を選択している。したがって，現代の青年 期タイ人の習慣的な食品・栄養素摂取量を把握す ることが可能であると考える. FFQ2 は NHES4 で 使用された食物摂取頻度調查票の食品項目にアル コール・嗜好飲料を加えたが，調味料や青年期タ イ人の摂取頻度が高い緑の野菜等の食品項目が不 足している。しかし，FFQ2 を実施する際は各食 品の目安量について写真集を見ながら回答を得た ため，正確な摂取量が把握できたと考える。ま た，栄養計算をする際は，日本食品成分表 2010 から FFQ1，FFQ2 に掲載されている食品項目につ いて荷重食品成分表を作成したものを使用したた め, タイ食品成分表や ASEAN 食品成分表では計 算できない栄養素についても算出が可能となっ た。 なお，タイ人栄養素摂取量を日本の食品成分 表を用いて算出することの可否については，現在 論文作成中である.

食物摂取頻度調査票の妥当性を評価する際は, 測定誤差が食物摂取頻度調查法より低いと思われ る科量式食事記録調查や 24 時間思い出し法によ る調査などから算出された栄養素と比較すること

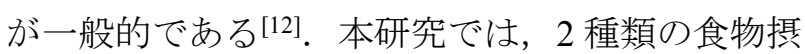
取頻度調查票を比較しているので, 得られた結果 をもって妥当性が検証されたとは言えない。しか し，異なる方法で作成され，実施された FFQか ら推定された各栄養素摂取量の相関や 3 分位の力 テゴリーの完全一致率が高かったことは, 本研究 で開発された FFQ が青年期タイ人の栄養素摂取 量を把握できる可能性を示している. 今後は，数 日間の食事記録調查や 24 時間思い出し法を実施 して妥当性を検証する必要がある。研究対象者は 女性の割合が高かったので，男性についても対象 者数を増やした解析が必要である. 本研究の対象 者の肥満の割合は，NHES4 における 15-29 歳の肥 満の割合より高值を示したことから，一般的な青 年期タイ人の栄養素摂取量を代表していない可能 性がある。

\section{5. 結論}

青年期タイ人の栄養摂取量を把握するために開 発された 2 種類の食物摂取頻度調査から推定され た栄養素摂取量は高い相関を示したことから，青 年期タイ人の習慣的な栄養素摂取量を把握するた めの利用可能性が示唆された. 


\section{謝辞}

本研究の調査にご協力いただいたチェンマイ・ ラジャバット大学の学生の皆様に感謝申し上げま す. 調査の場所を設定してくださった, ラジャバ ット大学科学技術学部のスタッフの皆様, 調査の 補助をしてくださった皆様に感謝申し上げます.

\section{付記}

本研究は, 大妻女子大学人間生活文化研究所平 成 27 年度共同研究プロジェクト（K2708）の助 成を受けて行われたものである.

\section{引用文献}

[1] Seubsman SA, et al., Socioeconomic status, sex, and obesity in a large national cohort of 15-87year-old open university students in Thailand. J Epidemiol, 2010. 20(1): p. 13-20.

[2] Yamborisut U, et al., Mo-Suwan, Prevalence of childhood and adolescent obesity in Thailand: a review. J Med Assoc Thai, 2014. 97(1): p. 44-51.

[3] 内閣府, 第 2 次食育基本計画. 2006.

[4] Kobayashi M, et al., Evaluation of Selfadministered Food Frequency Questionnaire: Validity of self-administered Food Frequency Questionnaire to Assess Food and Nutrient Intake in Adolescent Female. Bulletin of Showagakuin Junior College, 2006. 42: p. 32-44.

[5] Aekplakorn W, et al., Prevalence and management of diabetes and metabolic risk factors in Thai adults: the Thai National Health Examination Survey IV, 2009. Diabetes Care, 2011. 34(9): p. 1980-5.
[6] Bureau of Nutrition (BoN), Department of Health, Ministry of Public Health, Thailand, Thai Food Composition Tables. 2011.

[7] Institute of Nutrition, Mahidol University, Thailand, ASEAN Food Composition Database Electronic version 1. 2014.

[8] The Council for Science and Technology, Ministry of Education, Culture, Sports, Science, and Technology, Japan, Standard Tables of Food Composition in Japan, Fifth Revised version. 2010.

[9] Winichagoon $P$, Thailand nutrition in transition: situation and challenges of maternal and child nutrition. Asia Pac J Clin Nutr, 2013. 22(1): p. 615.

[10] Satheannoppakao W, et al., Energy and Macronutrient Intakes and Food Sources in Preschool Children: Thai NHES IV. J Med Assoc Thai, 2015. 98(10): p. 957-67.

[11] 山田均，他，世界の食文化 (5) タイ. 2003: 農 山漁村文化協会.

[12] Thompson, F.E, et al., Dietary assessment resource manual. J Nutr, 1994. 124(11 Suppl): p. 2245s$2317 \mathrm{~s}$ 
Table 1. FFQ1 または FFQ2 のみに載っている食品項目の比較

\begin{tabular}{|c|c|}
\hline FFQ1のみ載つている食品 & FFQ2のみに載つている食品 \\
\hline $\begin{array}{l}\text { チーズ } \\
\text { さつまあげ } \\
\text { ごま } \\
\text { 漬物以外の野菜 } \\
\text { 甘いパン(菓子パン) } \\
\text { 黒米 } \\
\text { もち } \\
\text { とうもろこし } \\
\text { 芋(さつまいも·じゃがいも) } \\
\text { わかめ·こんぶ } \\
\text { のり(焼のり·味付けのり) } \\
\text { プリンゼリー } \\
\text { チョコレート } \\
\text { アイスクリーム } \\
\text { スナック菓子(ポテトチップスなど) } \\
\text { 伝統菓子(もち米やうるち米を主材料にした菓子) } \\
\text { バター } \\
\text { ジャム・マーマレード } \\
\text { ドレッシング } \\
\text { マヨネーズ } \\
\text { ソース } \\
\text { ケチャツプ } \\
\text { ナンプラー } \\
\text { コーヒー牛乳 } \\
\text { ココア } \\
\text { ノーカロリー清涼飲料水(ダイエットコーラなど) } \\
\text { 飲料水(市販) } \\
\text { 焼酎 } \\
\text { カクテル・サワー }\end{array}$ & 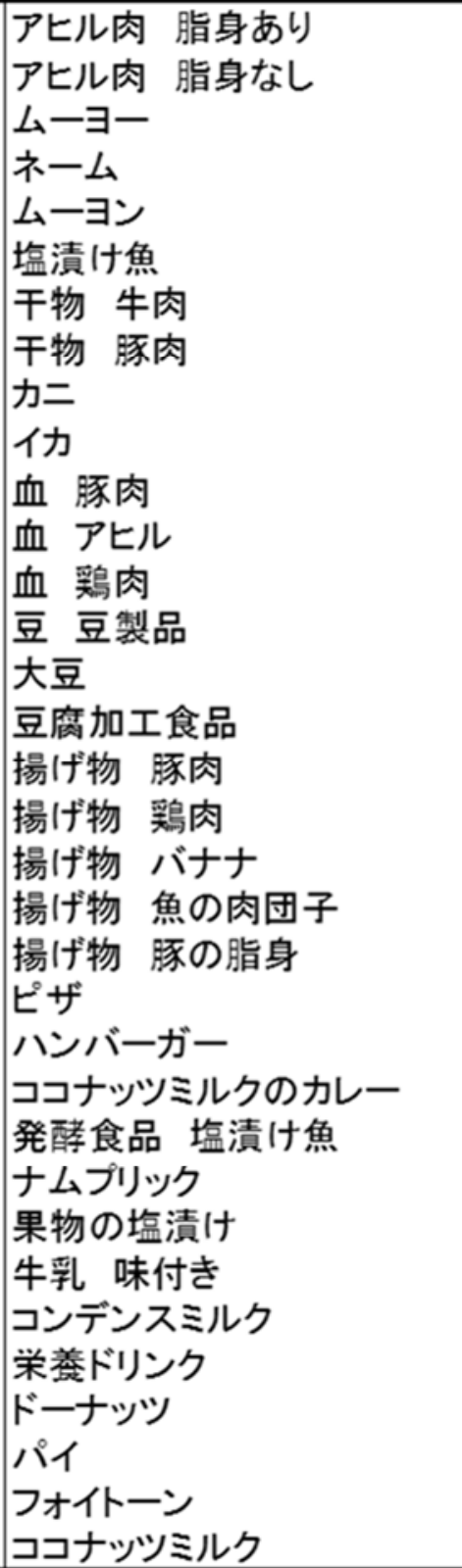 \\
\hline
\end{tabular}

Table 2 Characteristics of participants

\begin{tabular}{|c|c|c|c|c|c|c|}
\hline & women $(n=208)$ & & & men $(n=44)$ & & \\
\hline & Mean \pm SD & Minimum & Maximum & Mean \pm SD & Minimum & Maximum \\
\hline age & $20.2 \pm 1.5$ & 18.0 & 25.0 & $20.7 \pm 1.8$ & 18.0 & 26.0 \\
\hline height & $158.8 \pm 5.8$ & 140.0 & 170.0 & $171.8 \pm 6.5$ & 160.0 & 197.0 \\
\hline weight & $58.5 \pm 14.4$ & 35.1 & 112.0 & $69.4 \pm 15.1$ & 48.2 & 108.4 \\
\hline BMI & $22.9 \pm 5.1$ & 14.6 & 48.2 & $23.5 \pm 5.1$ & 16.9 & 37.5 \\
\hline $\mathrm{BMI}<18.5$ & $48(23.1)^{*}$ & & & $6(13.6)$ & & \\
\hline $25>\mathrm{BM} \geqq 18.5$ & $108(51.9)$ & & & $24(54.6)$ & & \\
\hline $\mathrm{BM} \geqq 25.0$ & $52(25.0)$ & & & $14(31.8)$ & & \\
\hline
\end{tabular}


Table 3 Energy and nutrient intake estimated from FFQ1 and FFQ2 in young Thai women and spearman correlation coefficient between FFQ1 and FFQ2 ( $\mathrm{n}=208$ )

\begin{tabular}{|c|c|c|c|c|c|c|c|c|c|c|c|c|}
\hline & \multicolumn{4}{|c|}{ FFQ1 } & \multicolumn{4}{|c|}{ FFQ2 } & \multirow{2}{*}{${ }^{\% d i f f e r e n c e}{ }^{1}$} & \multirow{2}{*}{ Pvalue $^{2}$} & \multicolumn{2}{|c|}{$r^{3}$} \\
\hline & mean & \pm & $\mathrm{sd}$ & median & mean & \pm & sd & median & & & crude value & $P$ value \\
\hline Energy (kcal) & 1829 & \pm & 1109 & 1564 & 2068 & \pm & 1409 & 1779 & 12 & 0.0004 & 0.68 & $<.0001$ \\
\hline Protein $(\mathrm{g})$ & 66.1 & \pm & 36.0 & 58.2 & 96.2 & \pm & 66.8 & 82.9 & 31 & $<.0001$ & 0.69 & $<.0001$ \\
\hline Total fat (g) & 49.9 & \pm & 29.6 & 43.9 & 65.1 & \pm & 52.0 & 51.3 & 23 & $<.0001$ & 0.69 & $<.0001$ \\
\hline SFA (g) & 18.39 & \pm & 11.57 & 15.65 & 21.70 & \pm & 17.00 & 16.51 & 15 & 0.0002 & 0.68 & $<.0001$ \\
\hline MUFA (g) & 17.95 & \pm & 10.61 & 15.46 & 23.06 & \pm & 18.43 & 17.90 & 22 & $<.0001$ & 0.66 & $<.0001$ \\
\hline PUFA (g) & 7.53 & \pm & 4.46 & 6.53 & 8.90 & \pm & 6.87 & 7.63 & 15 & 0.0002 & 0.68 & $<.0001$ \\
\hline n-3 PUFA (g) & 1.13 & \pm & 0.70 & 1.01 & 1.52 & \pm & 1.46 & 1.07 & 25 & $<.0001$ & 0.60 & $<.0001$ \\
\hline n-6 PUFA (g) & 6.98 & \pm & 4.27 & 5.92 & 9.51 & \pm & 7.61 & 7.72 & 27 & $<.0001$ & 0.66 & $<.0001$ \\
\hline Cholesterol (mg) & 291 & \pm & 172 & 264 & 463 & \pm & 362 & 392 & 37 & $<.0001$ & 0.68 & $<.0001$ \\
\hline Carbohydrate (g) & 269.5 & \pm & 185.6 & 222.6 & 268.3 & \pm & 180.5 & 230.2 & 0 & 0.9099 & 0.60 & $<.0001$ \\
\hline Soluble dietary fibers (g) & 2.7 & \pm & 1.8 & 2.2 & 2.9 & \pm & 2.7 & 2.1 & 8 & 0.1102 & 0.55 & $<.0001$ \\
\hline Insoluble dietary fibers ( $\mathrm{g}$ ) & 8.0 & \pm & 4.9 & 6.8 & 10.5 & \pm & 9.3 & 8.0 & 24 & $<.0001$ & 0.53 & $<.0001$ \\
\hline Total dietary fibers $(\mathrm{g}$ ) & 10.8 & \pm & 6.8 & 9.3 & 13.3 & \pm & 11.9 & 9.9 & 19 & 0.0003 & 0.55 & $<.0001$ \\
\hline Natrium ( mg) & 9986 & \pm & 5485 & 9132 & 3653 & \pm & 4119 & 2031 & -173 & $<.0001$ & 0.46 & $<.0001$ \\
\hline Potassium (mg) & 2531 & \pm & 1496 & 2236 & 2770 & \pm & 2140 & 2212 & 9 & 0.0254 & 0.68 & $<.0001$ \\
\hline Calcium (mg) & 574 & \pm & 369 & 500 & 487 & \pm & 385 & 395 & -18 & 0.0001 & 0.65 & $<.0001$ \\
\hline Magnesium (mg) & 229 & \pm & 132 & 204 & 282 & \pm & 214 & 219 & 19 & $<.0001$ & 0.68 & $<.0001$ \\
\hline Phosphorus (mg) & 976 & \pm & 536 & 874 & 1313 & \pm & 903 & 1098 & 26 & $<.0001$ & 0.72 & $<.0001$ \\
\hline Iron (mg) & 7.0 & \pm & 4.1 & 6.3 & 12.1 & \pm & 11.4 & 9.1 & 42 & $<.0001$ & 0.61 & $<.0001$ \\
\hline Zinc (mg) & 9.0 & \pm & 5.0 & 7.8 & 11.9 & \pm & 8.2 & 10.6 & 25 & $<.0001$ & 0.70 & $<.0001$ \\
\hline Copper (mg) & 1.10 & \pm & 0.66 & 0.94 & 1.56 & \pm & 1.22 & 1.29 & 29 & $<.0001$ & 0.61 & $<.0001$ \\
\hline Manganese (mg) & 2.97 & \pm & 1.69 & 2.66 & 3.47 & \pm & 2.81 & 2.54 & 14 & 0.0017 & 0.53 & $<.0001$ \\
\hline lodine $(\mu \mathrm{g})$ & 437 & \pm & 273 & 389 & 266 & \pm & 183 & 226 & -64 & $<.0001$ & 0.62 & $<.0001$ \\
\hline Serene $(\mu \mathrm{g})$ & 27 & \pm & 18 & 23 & 79 & \pm & 75 & 59 & 66 & $<.0001$ & 0.62 & $<.0001$ \\
\hline Chrome $(\mu \mathrm{g})$ & 6 & \pm & 5 & 4 & 6 & \pm & 5 & 4 & -2 & 0.7434 & 0.55 & $<.0001$ \\
\hline Molybdic ( $\mu \mathrm{g})$ & 114 & \pm & 84 & 97 & 166 & \pm & 112 & 142 & 31 & $<.0001$ & 0.59 & $<.0001$ \\
\hline Retinol ( $\mu \mathrm{gRE})$ & 955 & \pm & 1219 & 509 & 3701 & \pm & 6359 & 1501 & 74 & $<.0001$ & 0.59 & $<.0001$ \\
\hline Alpha-carotene $(\mu \mathrm{g})$ & 131 & \pm & 124 & 96 & 70 & \pm & 100 & 36 & -87 & $<.0001$ & 0.37 & $<.0001$ \\
\hline Beta-carotene $(\mu \mathrm{g})$ & 5470 & \pm & 4383 & 4391 & 1115 & \pm & 1310 & 665 & -390 & $<.0001$ & 0.30 & $<.0001$ \\
\hline Cryptoxanthin ( $\mu \mathrm{g})$ & 90 & \pm & 65 & 72 & 165 & \pm & 255 & 84 & 45 & $<.0001$ & 0.54 & $<.0001$ \\
\hline Vitamin A $(\mu \mathrm{g})$ & 1888 & \pm & 1546 & 1408 & 3905 & \pm & 6440 & 1688 & 52 & $<.0001$ & 0.54 & $<.0001$ \\
\hline Vitamin D $(\mu \mathrm{g})$ & 1.3 & \pm & 1.0 & 1.1 & 4.3 & \pm & 6.5 & 2.8 & 71 & $<.0001$ & 0.45 & $<.0001$ \\
\hline Alpha-tocopherol (mg) & 7.6 & \pm & 5.0 & 6.2 & 6.9 & \pm & 5.9 & 5.0 & -10 & 0.0716 & 0.57 & $<.0001$ \\
\hline Beta-tocopherol (mg) & 0.1 & \pm & 0.1 & 0.1 & 0.4 & \pm & 0.4 & 0.3 & 64 & $<.0001$ & 0.54 & $<.0001$ \\
\hline Gamma-tocopherol (mg) & 6.5 & \pm & 4.7 & 5.5 & 4.0 & \pm & 3.9 & 2.6 & -62 & $<.0001$ & 0.63 & $<.0001$ \\
\hline Delta-tocopherol (mg) & 1.3 & \pm & 1.3 & 0.9 & 1.3 & \pm & 1.4 & 0.7 & -1 & 0.9272 & 0.58 & $<.0001$ \\
\hline Vitamin $\mathrm{K}(\mu \mathrm{g})$ & 284 & \pm & 201 & 248 & 62 & \pm & 48 & 49 & -360 & $<.0001$ & 0.43 & $<.0001$ \\
\hline Vitamin $B_{1}(\mathrm{mg})$ & 1.19 & \pm & 0.71 & 1.00 & 1.66 & \pm & 1.18 & 1.42 & 29 & $<.0001$ & 0.65 & $<.0001$ \\
\hline Vitamin $B_{2}(\mathrm{mg})$ & 1.59 & \pm & 0.94 & 1.39 & 2.17 & \pm & 1.86 & 1.63 & 27 & $<.0001$ & 0.65 & $<.0001$ \\
\hline Niacin (mgNE) & 13.1 & \pm & 7.9 & 11.5 & 22.4 & \pm & 16.9 & 19.0 & 41 & $<.0001$ & 0.66 & $<.0001$ \\
\hline Vitamin $B_{6}(\mathrm{mg})$ & 1.14 & \pm & 0.62 & 1.02 & 1.53 & \pm & 1.17 & 1.30 & 26 & $<.0001$ & 0.66 & $<.0001$ \\
\hline Vitamin $B_{12}(\mu g)$ & 5.0 & \pm & 4.6 & 3.4 & 17.3 & \pm & 24.2 & 9.4 & 71 & $<.0001$ & 0.58 & $<.0001$ \\
\hline Folate $(\mu \mathrm{g})$ & 318 & \pm & 202 & 265 & 499 & \pm & 630 & 308 & 36 & $<.0001$ & 0.56 & $<.0001$ \\
\hline Pantothenic acid (mg) & 6.54 & \pm & 3.58 & 5.77 & 9.09 & \pm & 7.32 & 7.26 & 28 & $<.0001$ & 0.70 & $<.0001$ \\
\hline Biotin $(\mu \mathrm{g})$ & 24.9 & \pm & 20.4 & 19.4 & 69.4 & \pm & 96.4 & 41.3 & 64 & $<.0001$ & 0.61 & $<.0001$ \\
\hline Vitamin C (mg) & 80 & \pm & 52 & 69 & 137 & \pm & 171 & 78 & 42 & $<.0001$ & 0.48 & $<.0001$ \\
\hline Salt (g) & 25.3 & \pm & 13.9 & 23.2 & 7.4 & \pm & 8.3 & 3.9 & -240 & $<.0001$ & 0.46 & $<.0001$ \\
\hline Daidzein (mg) & 1.4 & \pm & 2.7 & 0.6 & 6.0 & \pm & 9.5 & 2.1 & 77 & $<.0001$ & 0.42 & $<.0001$ \\
\hline Genistain (mg) & 2.1 & \pm & 4.4 & 0.9 & 9.1 & \pm & 14.3 & 3.5 & 77 & $<.0001$ & 0.42 & $<.0001$ \\
\hline
\end{tabular}

1\%difference; (FFQ2 - FFQ1)/FFQ2 * 100

${ }^{2}$ Paired Ttest

${ }^{3}$ Spearman correlation cofficient 
Table 4 Energy and nutrient intake estimated from FFQ1 and FFQ2 in young Thai men and spearman correlation coefficient between FFQ1 and FFQ2 ( $n=44$ )

\begin{tabular}{|c|c|c|c|c|c|c|c|c|c|c|c|}
\hline & \multicolumn{4}{|l|}{ FFQ1 } & \multicolumn{3}{|l|}{ FFQ2 } & \multirow{2}{*}{$\%$ difference ${ }^{1}$} & \multirow{2}{*}{ Pvalue $^{2}$} & \multicolumn{2}{|l|}{$r^{3}$} \\
\hline & mean & \pm & $\mathrm{sd}$ & median & mean & $\pm \mathrm{sd}$ & median & & & crude value & $P$ value \\
\hline Energy (kcal) & 2134 & \pm & 1503 & 1758 & 2042 & \pm 1396 & 1686 & -5 & 0.5713 & 0.76 & $<.0001$ \\
\hline Protein (g) & 68.9 & \pm & 49.4 & 63.7 & 94.8 & \pm 74.2 & 79.2 & 27 & 0.0002 & 0.75 & $<.0001$ \\
\hline Total fat $(\mathrm{g})$ & 50.1 & \pm & 35.6 & 44.2 & 66.5 & \pm 59.8 & 53.3 & 25 & 0.0055 & 0.75 & $<.0001$ \\
\hline SFA (g) & 17.84 & \pm & 13.42 & 15.06 & 22.10 & \pm 18.62 & 19.80 & 19 & 0.0158 & 0.76 & $<.0001$ \\
\hline MUFA (g) & 18.18 & \pm & 12.73 & 15.98 & 24.61 & \pm 21.94 & 20.17 & 26 & 0.0051 & 0.75 & $<.0001$ \\
\hline PUFA (g) & 8.04 & \pm & 5.58 & 7.41 & 9.09 & \pm 9.63 & 6.79 & 12 & 0.2799 & 0.72 & $<.0001$ \\
\hline n-3 PUFA (g) & 1.28 & \pm & 0.95 & 1.02 & 1.49 & \pm 1.77 & 1.03 & 14 & 0.2707 & 0.67 & $<.0001$ \\
\hline n-6 PUFA (g) & 7.41 & \pm & 5.09 & 6.74 & 9.37 & \pm 9.08 & 6.85 & 21 & 0.0429 & 0.68 & $<.0001$ \\
\hline Cholesterol (mg) & 317 & \pm & 246 & 247 & 512 & \pm 489 & 413 & 38 & 0.0011 & 0.71 & $<.0001$ \\
\hline Carbohydrate (g) & 286.0 & \pm & 195.2 & 231.9 & 243.9 & \pm 146.5 & 208.6 & -17 & 0.0383 & 0.73 & $<.0001$ \\
\hline Soluble dietary fibers (g) & 2.5 & \pm & 2.0 & 1.9 & 2.3 & \pm 1.8 & 2.0 & -6 & 0.4582 & 0.78 & $<.0001$ \\
\hline Insoluble dietary fibers $(\mathrm{g})$ & 7.2 & \pm & 5.1 & 5.5 & 8.7 & \pm 7.2 & 7.3 & 18 & 0.0352 & 0.75 & $<.0001$ \\
\hline Total dietary fibers $(\mathrm{g})$ & 9.8 & \pm & 7.4 & 7.5 & 11.0 & \pm 8.9 & 9.4 & 10 & 0.1749 & 0.76 & $<.0001$ \\
\hline Natrium ( $\mathrm{mg}$ ) & 10124 & \pm & 6277 & 8433 & 2779 & \pm 3423 & 1720 & -264 & $<.0001$ & 0.59 & $<.0001$ \\
\hline Potassium (mg) & 2587 & \pm & 1964 & 2110 & 2424 & \pm 1750 & 2121 & -7 & 0.3468 & 0.78 & $<.0001$ \\
\hline Calcium (mg) & 549 & \pm & 442 & 497 & 375 & \pm 283 & 315 & -46 & 0.0013 & 0.68 & $<.0001$ \\
\hline Magnesium (mg) & 249 & \pm & 186 & 209 & 248 & \pm 187 & 197 & 0 & 0.951 & 0.79 & $<.0001$ \\
\hline Phosphorus (mg) & 1028 & \pm & 733 & 890 & 1247 & \pm 919 & 1045 & 18 & 0.0055 & 0.78 & $<.0001$ \\
\hline Iron (mg) & 7.1 & \pm & 5.4 & 5.9 & 11.8 & \pm 14.3 & 7.6 & 40 & 0.006 & 0.71 & $<.0001$ \\
\hline Zinc (mg) & 9.1 & \pm & 6.0 & 8.0 & 12.4 & \pm 9.9 & 9.6 & 27 & 0.0013 & 0.76 & $<.0001$ \\
\hline Copper (mg) & 1.11 & \pm & 0.81 & 0.99 & 1.43 & \pm 1.22 & 1.19 & 22 & 0.0046 & 0.78 & $<.0001$ \\
\hline Manganese (mg) & 3.04 & \pm & 2.10 & 2.36 & 3.08 & \pm 2.47 & 2.21 & 1 & 0.9025 & 0.64 & $<.0001$ \\
\hline lodine $(\mu \mathrm{g})$ & 535 & \pm & 369 & 412 & 253 & \pm 155 & 216 & -111 & $<.0001$ & 0.66 & $<.0001$ \\
\hline Serene $(\mu \mathrm{g})$ & 30 & \pm & 24 & 27 & 76 & \pm 79 & 54 & 60 & $<.0001$ & 0.59 & $<.0001$ \\
\hline Chrome $(\mu \mathrm{g})$ & 5 & \pm & 5 & 4 & 5 & \pm 4 & 4 & -7 & 0.5792 & 0.57 & $<.0001$ \\
\hline Molybdic $(\mu \mathrm{g})$ & 126 & \pm & 109 & 96 & 158 & \pm 134 & 123 & 21 & 0.0086 & 0.67 & $<.0001$ \\
\hline Retinol ( $\mu \mathrm{gRE})$ & 935 & \pm & 1374 & 438 & 4396 & \pm 8101 & 1366 & 79 & 0.0071 & 0.57 & $<.0001$ \\
\hline Alpha-carotene $(\mu \mathrm{g})$ & 102 & \pm & 94 & 73 & 61 & \pm 88 & 21 & -68 & 0.0173 & 0.48 & 0.001 \\
\hline Beta-carotene $(\mu \mathrm{g})$ & 4246 & \pm & 3673 & 3553 & 795 & \pm 705 & 645 & -434 & $<.0001$ & 0.56 & $<.0001$ \\
\hline Cryptoxanthin $(\mu \mathrm{g})$ & 84 & \pm & 64 & 66 & 111 & \pm 139 & 81 & 24 & 0.2103 & 0.70 & $<.0001$ \\
\hline Vitamin A $(\mu \mathrm{g})$ & 1661 & \pm & 1596 & 1192 & 4544 & \pm 8136 & 1627 & 63 & 0.0234 & 0.49 & 0.0008 \\
\hline Vitamin D $(\mu \mathrm{g})$ & 1.7 & \pm & 1.6 & 1.1 & 4.7 & \pm 7.9 & 2.7 & 65 & 0.009 & 0.51 & 0.0004 \\
\hline Alpha-tocopherol (mg) & 6.9 & \pm & 5.1 & 5.2 & 6.1 & \pm 4.9 & 4.9 & -13 & 0.1903 & 0.77 & $<.0001$ \\
\hline Beta-tocopherol (mg) & 0.1 & \pm & 0.1 & 0.1 & 0.3 & \pm 0.3 & 0.2 & 55 & 0.0002 & 0.60 & $<.0001$ \\
\hline Gamma-tocopherol (mg) & 6.8 & \pm & 5.6 & 5.1 & 3.3 & \pm 4.8 & 2.2 & -109 & $<.0001$ & 0.73 & $<.0001$ \\
\hline Delta-tocopherol (mg) & 1.4 & \pm & 1.7 & 0.9 & 0.9 & \pm 1.6 & 0.5 & -52 & 0.0029 & 0.63 & $<.0001$ \\
\hline Vitamin K $(\mu \mathrm{g})$ & 234 & \pm & 170 & 196 & 68 & \pm 70 & 54 & -243 & $<.0001$ & 0.50 & 0.0005 \\
\hline Vitamin $B_{1}(\mathrm{mg})$ & 1.19 & \pm & 0.95 & 0.98 & 1.62 & \pm 1.22 & 1.42 & 27 & 0.0006 & 0.75 & $<.0001$ \\
\hline Vitamin $B_{2}(\mathrm{mg})$ & 1.63 & \pm & 1.25 & 1.41 & 2.17 & \pm 2.16 & 1.67 & 25 & 0.0231 & 0.64 & $<.0001$ \\
\hline Niacin (mgNE) & 15.6 & \pm & 11.8 & 12.1 & 23.1 & \pm 19.1 & 20.2 & 32 & 0.0004 & 0.73 & $<.0001$ \\
\hline Vitamin $\mathrm{B}_{6}(\mathrm{mg})$ & 1.27 & \pm & 0.92 & 0.96 & 1.51 & \pm 1.19 & 1.27 & 16 & 0.0591 & 0.75 & $<.0001$ \\
\hline Vitamin $B_{12}(\mu \mathrm{g})$ & 5.6 & \pm & 5.8 & 3.4 & 18.4 & \pm 30.3 & 8.1 & 69 & 0.0039 & 0.51 & 0.0004 \\
\hline Folate $(\mu \mathrm{g})$ & 324 & \pm & 246 & 250 & 527 & \pm 757 & 282 & 39 & 0.0587 & 0.60 & $<.0001$ \\
\hline Pantothenic acid (mg) & 6.68 & \pm & 4.53 & 5.98 & 7.26 & \pm 9.12 & 7.19 & 8 & 0.0095 & 0.70 & $<.0001$ \\
\hline Biotin $(\mu \mathrm{g})$ & 28.1 & \pm & 26.6 & 19.5 & 77.2 & \pm 125.7 & 37.9 & 64 & 0.0076 & 0.59 & $<.0001$ \\
\hline Vitamin C (mg) & 86 & \pm & 70 & 61 & 112 & \pm 105 & 69 & 23 & 0.1242 & 0.57 & $<.0001$ \\
\hline Salt (g) & 25.7 & \pm & 15.9 & 21.4 & 5.9 & \pm 6.7 & 3.8 & -337 & $<.0001$ & 0.60 & $<.0001$ \\
\hline Daidzein (mg) & 1.2 & \pm & 1.7 & 0.4 & 5.5 & \pm 15.2 & 1.2 & 78 & 0.0535 & 0.48 & 0.0009 \\
\hline Genistain (mg) & 1.9 & \pm & 2.7 & 0.6 & 8.3 & \pm 22.8 & 2.1 & 77 & 0.0543 & 0.49 & 0.0008 \\
\hline
\end{tabular}

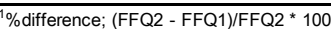

${ }^{2}$ Paired Ttest

${ }^{3}$ Spearman correlation cofficient 
Table 5 Nutrient intake estimated from FFQ1 classified with tertile of the intake estimated from FFQ2 for correspondig nutrient and percentage of same category (women; $\mathrm{n}=208$ )

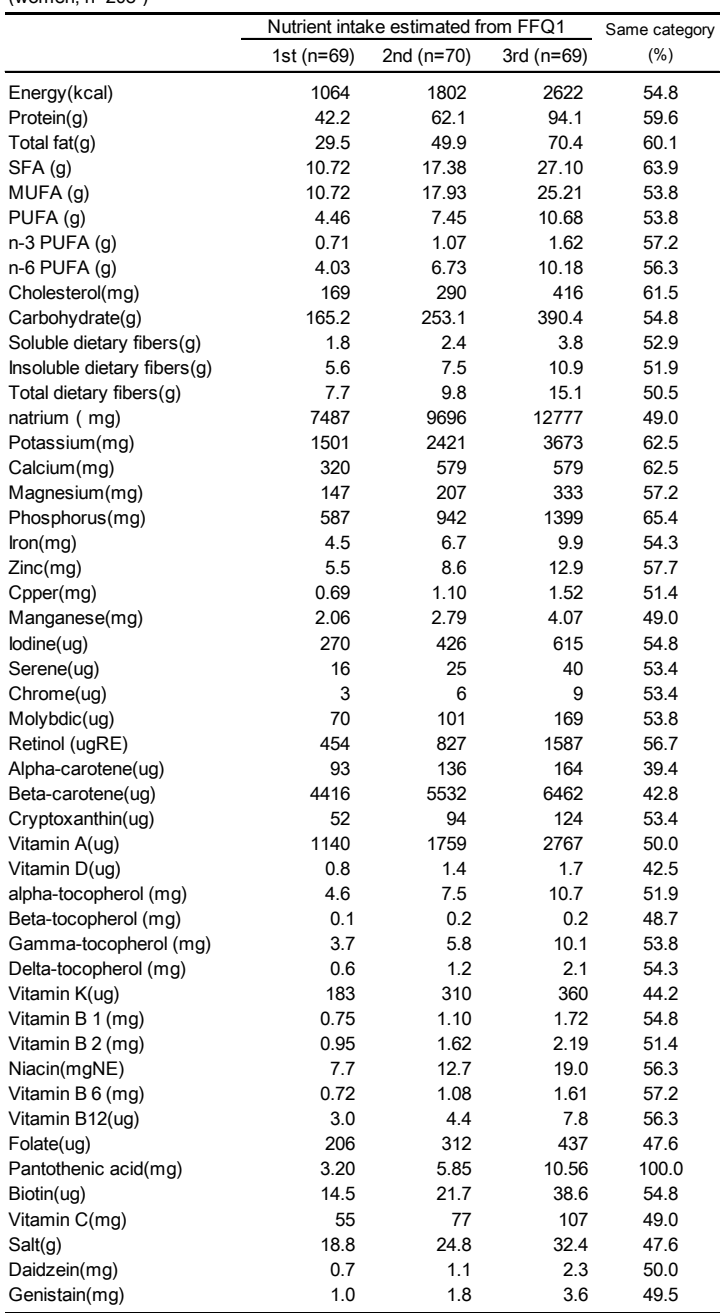

Table 6 Nutrient intake estimated from FFQ1 classified with tertile of the intake estimated from FFQ2 for correspondig nutrient and percentage of same category (men; $\mathrm{n}=44$ )

\begin{tabular}{|c|c|c|c|c|}
\hline & \multicolumn{3}{|c|}{ Nutrient intake estimated from FFQ1 } & \multirow{2}{*}{$\begin{array}{c}\text { Same categon } \\
(\%)\end{array}$} \\
\hline & 1st $(n=14)$ & 2nd $(n=15)$ & $3 r d(n=15)$ & \\
\hline Energy (kcal) & 981 & 1932 & 3413 & 68.2 \\
\hline Protein (g) & 32.6 & 64.7 & 107.1 & 54.5 \\
\hline Total fat $(\mathrm{g})$ & 22.9 & 47.7 & 78.0 & 56.8 \\
\hline SFA (g) & 7.79 & 16.99 & 28.06 & 61.4 \\
\hline MUFA (g) & 8.20 & 17.92 & 27.75 & 61.4 \\
\hline PUFA (g) & 4.17 & 7.14 & 12.54 & 59.1 \\
\hline n-3 PUFA (g) & 0.64 & 1.17 & 1.98 & 52.3 \\
\hline $\mathrm{n}-6$ PUFA (g) & 3.97 & 6.68 & 11.36 & 50.0 \\
\hline Cholesterol (mg) & 132 & 303 & 504 & 52.3 \\
\hline Carbohydrate (g) & 158.8 & 235.3 & 455.4 & 54.5 \\
\hline Soluble dietary fibers (g) & 1.0 & 2.0 & 4.3 & 65.9 \\
\hline Insoluble dietary fibers (g) & 3.2 & 6.6 & 11.5 & 61.4 \\
\hline Total dietary fibers (g) & 4.3 & 9.0 & 15.9 & 61.4 \\
\hline Natrium ( $\mathrm{mg}$ ) & 6776 & 9056 & 14318 & 52.3 \\
\hline Potassium (mg) & 1129 & 2282 & 4253 & 70.5 \\
\hline Calcium (mg) & 225 & 584 & 815 & 54.5 \\
\hline Magnesium (mg) & 107 & 237 & 394 & 68.2 \\
\hline Phosphorus (mg) & 486 & 928 & 1634 & 59.1 \\
\hline Iron (mg) & 3.1 & 6.9 & 11.0 & 56.8 \\
\hline Zinc (mg) & 4.7 & 8.8 & 13.5 & 54.5 \\
\hline Copper (mg) & 0.55 & 1.00 & 1.74 & 65.9 \\
\hline Manganese $(\mathrm{mg})$ & 1.89 & 2.41 & 4.76 & 50.0 \\
\hline lodine $(\mu \mathrm{g})$ & 273 & 486 & 828 & 56.8 \\
\hline Serene $(\mu \mathrm{g})$ & 14 & 30 & 46 & 68.9 \\
\hline Chrome $(\mu \mathrm{g})$ & 2 & 5 & 9 & 52.3 \\
\hline Molybdic ( $\mu \mathrm{g})$ & 66 & 102 & 204 & 54.5 \\
\hline Retinol ( $\mu g R E)$ & 463 & 1183 & 1127 & 50.0 \\
\hline Alpha-carotene $(\mu \mathrm{g})$ & 44 & 126 & 131 & 59.1 \\
\hline Beta-carotene $(\mu \mathrm{g})$ & 1913 & 4852 & 5819 & 52.3 \\
\hline Cryptoxanthin ( $\mu \mathrm{g})$ & 29 & 95 & 123 & 65.9 \\
\hline Vitamin A $(\mu \mathrm{g})$ & 812 & 2268 & 1848 & 59.1 \\
\hline Vitamin D $(\mu \mathrm{g})$ & 0.9 & 1.4 & 2.6 & 43.2 \\
\hline Alpha-tocopherol $(\mathrm{mg})$ & 3.1 & 5.5 & 11.8 & 75.0 \\
\hline Beta-tocopherol (mg) & 0.1 & 0.2 & 0.2 & 45.5 \\
\hline Gamma-tocopherol (mg) & 2.8 & 5.8 & 11.6 & 56.8 \\
\hline Delta-tocopherol (mg) & 0.5 & 1.3 & 2.4 & 63.6 \\
\hline Vitamin K $(\mu \mathrm{g})$ & 171 & 201 & 326 & 45.5 \\
\hline Vitamin $B_{1}(\mathrm{mg})$ & 0.51 & 1.12 & 1.89 & 61.4 \\
\hline Vitamin $B_{2}(\mathrm{mg})$ & 0.75 & 1.75 & 2.34 & 59.1 \\
\hline Niacin (mgNE) & 6.3 & 15.3 & 24.6 & 59.1 \\
\hline Vitamin $\mathrm{B}_{6}(\mathrm{mg})$ & 0.59 & 1.23 & 1.94 & 65.9 \\
\hline Vitamin $B_{12}(\mu \mathrm{g})$ & 3.0 & 5.9 & 7.7 & 54.5 \\
\hline Folate $(\mu \mathrm{g})$ & 164 & 337 & 460 & 63.6 \\
\hline Pantothenic acid (mg) & 2.36 & 5.68 & 11.73 & 100.0 \\
\hline Biotin $(\mu \mathrm{g})$ & 14.1 & 26.6 & 42.6 & 61.4 \\
\hline Vitamin C $(\mathrm{mg})$ & 47 & 96 & 113 & 47.7 \\
\hline Salt (g) & 16.8 & 23.2 & 36.4 & 61.4 \\
\hline Daidzein $(\mathrm{mg})$ & 0.6 & 1.0 & 2.0 & 47.7 \\
\hline Genistain (mg) & 1.0 & 1.6 & 3.1 & 47.7 \\
\hline
\end{tabular}

\section{Abstract}

We developed two kind of semi-quantitative food frequency questionnaire (FFQ) for estimating habitual nutrient intake from young Thai. One FFQ is developed to modify the Japanese FFQ according to the data from dietary record of 56 young Thai (Thai_FFQ1). The other FFQ is developed to add the portion size of intake per one meal to the FFQ using Thai national nutritional survey (Thai_FFQ2). To increase the precision of answer of Thai_FFQ2, we developed photographic inventory which listed food items with each portion size. Both Thai_FFQ1 andThai_FFQ2 were conducted 252 Thai young and foods and nutrient intake were calculated. We found high correlation between nutrients estimated by Thai_FFQ1 and those by Thai_FFQ2. 


\section{小林 実夏（こばやし みなつ）}

現職 : 大妻女子大学家政学部食物学科 准教授

大妻女子大学大学院家政学研究科修士課程修了.

東邦大学大学院医学研究科 (社会医学) 博士課程単位取得満期退学.

専門は栄養疫学. 食事評価法に関する研究が中心であるが，現在は，異なる食文化・環境における青年の 食習慣・食育に関する研究も行っている.

最近の主な原著 :

1. 青年女性のうま味感受性と食習慣との関連（Japanese J Taste Smell Res. 2015; 22(3)）

2. Validity of food frequency questionnaires to estimate long-chain polyunsaturated fatty acid intake among Japanese women in early and late pregnancy. J epidemiol., 2016 (in press) 